Web Jurnal:

http://ejournal.kemenperin.go.id/jli

Kementerian

Perindustrian

REPUBLIK INDONESIA

\title{
Pengaruh konsentrasi ekstrak katekin Uncaria gambir terhadap umur simpan ikan teri (Stolephorus sp.)
}

\section{Effect of catechin concentration from gambir (Uncaria gambir Roxb.) on shelf life of anchovies (Stolephorus sp.)}

\author{
Gustri Yeni*1, Yurnalis ${ }^{2}$, dan Piko Andika ${ }^{3}$ \\ Balai Riset dan Standardisasi Industri Padang \\ J1. Raya LIK No. 23 Ulu Gadut, Padang, Indonesia \\ 2 Dosen Teknologi Hasil Pertanian, Fakultas Pertanian, Universitas Ekasakti Padang \\ Jl. Veteran Dalam No.26B, Padang Pasir, Padang, Indonesia \\ 3 Jurusan Teknologi Hasil Pertanian, Fakultas Pertanian, Universitas Ekasakti Padang \\ J1. Veteran Dalam No.26B, Padang Pasir, Padang, Indonesia \\ * e-mail: gustry87@gmail.com
}

\begin{tabular}{l}
\hline INFO ARTIKEL \\
\hline Sejarah artikel: \\
Diterima: \\
11 Mei 2021 \\
Direvisi: \\
24 Juni 2021 \\
Diterbitkan: \\
30 Juni 2021
\end{tabular}

Kata kunci:

katekin;

gambir;

konsentrasi;

ikan teri;

umur simpan

Keywords:

catechins;

gambier;

concentration;

anchovy;

shelf life

\begin{abstract}
ABSTRAK
Penelitian ini bertujuan untuk mengetahui pengaruh konsentrasi katekin dari Uncaria gambir terhadap ketahanan simpan ikan teri. Pengawetan ikan teri pada penelitian ini dilakukan melalui proses perendaman ikan teri dalam larutan katekin (konsentrasi 0\%-15\%) dengan perbandingan 1:4 selama \pm 2 jam. Ikan teri hasil perlakuan dikeringkan dalam oven pada suhu $\pm 50^{\circ} \mathrm{C}$ selama $12-24$ jam dan dikemas menggunakan plastik polipropilen (PP). Untuk mengetahui ketahanan simpan ikan teri dilakukan penyimpanan selama 30 hari, setiap 15 hari dilakukan analisis untuk mengetahui mutu produk. Hasil penelitian menunjukkan ikan teri yang diawetkan menggunakan katekin pada konsentrasi $10 \%$ (A3) dapat mengurangi jumlah bakteri $\left(1,10 \times 10^{5}\right.$ koloni $\left./ \mathrm{g}\right)$ dengan kadar air $18,1339 \%$ dan abu $10,5358 \%$. Uji organoleptik pada konsentrasi yang sama memiliki nilai sangat suka-suka terhadap tekstur dan aroma, tetapi warna kurang disukai panelis karena menghasilkan penampakan lebih gelap dibandingkan tanpa perendaman katekin (A1). Pengujian ketahanan simpan produk sampai 30 hari masih memenuhi standar ikan teri kering (SNI.01-3391-2000) dan uji organoleptik mengalami penurunan terhadap nilai tekstur dan warna, dimana produk menjadi kurang kompak dan warna menjadi lebih gelap.
\end{abstract}

\begin{abstract}
This study aims to determine the effect of the concentration of catechins from Uncaria gambir on the shelf life of anchovies. Preservation of anchovies in this study was carried out by soaking them in a catechin solution ( $0 \%-15 \%$ concentration) with a ratio of $1: 4$ for \pm 2 hours. The treated anchovies were dried in an oven at a temperature of $\pm 50^{\circ} \mathrm{C}$ for 12-24 hours and packaged using polypropylene (PP) plastic. To determine the shelf life of anchovies, storage was carried out for 30 days, every 15 days an analysis was carried out to determine the quality of the product. The results showed that anchovy preserved using catechins at a concentration of $10 \%$ (A3) can reduce the number of bacteria $\left(1.10 \times 10^{5}\right.$ colonies $\left.g^{-1}\right)$ with water and ash content were $18.1339 \%$ and $10.5358 \%$ respectively. The organoleptic test at the same concentration had a very favorable value for texture and aroma, but the panelists did not like the color because it produced a darker appearance than without immersion in catechin (A1). The product shelf life test for up to 30 days still met the standard of dried anchovy (SNI.01-3391-2000) and the organoleptic test had decreased the texture and color values, where the product became less compact and the color became darker.
\end{abstract}




\section{Pendahuluan}

Ikan teri (Stolephorus sp.) merupakan jenis ikan pelagis kecil yang bernilai ekonomis tinggi dan banyak diminati masyarakat. Ikan teri memiliki kandungan protein tinggi yang sangat disukai bakteri dan salah satu penyebab penurunan mutu jika tidak segera diolah. Bakteri dapat mengurai protein dengan bantuan enzim dan memecah protein menjadi molekul sederhana seperti amoniak dan unsur-unsur sebagai nitrogen $(\mathrm{N})$. Mikroorganisme pada suatu bahan memiliki kemampuan menginfeksi dan menimbulkan penyakit serta merusak bahan pangan. Mikroorganisme dapat disingkirkan dengan cara dihambat atau dibunuh secara fisik maupun kimia (Magdalena and Kusnadi, 2015; Melia et al., 2015; Rosaini et al., 2015; Sari et al., 2017; Silvia et al., 2015).

Kerusakan ikan teri selama ini umumnya diatasi dengan cara pengawetan melalui pengeringan dan penggaraman. Pengawetan ikan teri dengan pengeringan secara langsung menggunakan matahari memiliki kekurangan, yaitu tekstur yang tidak merata disebabkan suhu yang tidak konstan. Pengeringan menggunakan alat membutuhkan biaya yang cukup mahal dengan produk yang tidak sesuai harapan seperti tekstur terlalu keras atau overcook (Sari et al., 2020; Silvia et al., 2015).

Pengawetan menggunakan garam menyebabkan ikan teri memiliki tekstur tidak beraturan dan hanya dapat dikonsumsi orang tertentu karena rasanya yang asin. Untuk itu perlu didapatkan pengawet alami untuk ikan teri yang aman dikonsumsi. Salah satu pengawet alami yang cukup tersedia adalah ekstrak katekin dari daun dan ranting gambir (Uncaria gambir Roxb.).

Katekin merupakan senyawa flavonoid dan komponen fitokimia utama pada daun gambir, yaitu sekitar $40 \%$ yang berfungsi sebagai antimikroba. Fungsi katekin selain sebagai antimikroba juga sebagai antioksidan sehingga katekin dapat dikategorikan sebagai pengawet yang fungsional (Anova and Kamsina, 2018; Kamsina et al., 2020; Melia et al., 2015; Pambayun et al., 2007; Sari et al., 2020, 2017; Suraini et al., 2015; Yeni et al., 2014).

Beberapa penelitian telah membuktikan bahwa ekstrak katekin dari gambir mampu mengawetkan bahan pangan berbasis protein (Kamsina et al., 2020; Melia et al., 2015; Sari et al., 2017). Senyawa katekin yang dipertemukan dengan protein pada suatu bahan pangan akan membentuk komplek katekin protein dan sifat yang memiliki kemampuan untuk menghambat bakteri dengan cara mengikat dinding sel. Pengikatan antara $(+)$-katekin terjadi pada peptida, dimana pada kondisi ini sel mengalami kebocoran dan membuat bakteri mati. Efektifitas penggunaan pengawet katekin dari gambir dilakukan dengan cara perendaman selama waktu tertentu untuk menghambat bakteri yang terdapat pada ikan (Magdalena and Kusnadi, 2015; Melia et al., 2015; Sari et al., 2017).

Kandungan katekin pada gambir menjadi zat yang potensial untuk meningkatkan umur simpan pada ikan teri. Umur simpan pada suatu bahan pangan adalah rentang waktu yang dimiliki suatu produk mulai dari produksi hingga konsumsi sebelum produk mengalami penurunan mutu. Perubahan mutu suatu produk diukur secara fisik, kimia maupun dari tingkat penerimaan secara sensori (Asiah et al., 2018). Umur simpan merupakan sebagai bentuk jaminan keamanan pangan dan sebagai indikator mutu suatu produk (Herawati, 2008).

Potensi katekin dari gambir sebagai antimikrobia sekaligus antioksidan, diharapkan mampu untuk memperpanjang umur simpan ikan. Hal ini juga didukung ketersediaan gambir yang cukup banyak sehingga memungkinkan dapat dikembangkan sebagai pengawet pangan diantaranya ikan teri.

Berdasarkan uraian di atas, perlu dilakukan penelitian untuk mendapatkan konsentrasi katekin dari gambir terhadap ketahanan simpan ikan teri yang sesuai sehingga ikan teri dapat diawetkan dengan cita rasa yang disukai dan fungsional. Penelitian ini juga diharapkan sebagai upaya pemanfaatan produk turunan gambir secara lebih luas dalam industri pangan.

\section{Metode}

Penelitian ini dilakukan di laboratorium proses Baristand Industri Padang dan laboratorium Universitas Ekasakti Padang, Fakultas Teknologi Hasil Pertanian untuk pembuatan produk katekin dan pengujian produk. Bahan baku yang digunakan dalam penelitian adalah ikan teri segar yang diperoleh dari Bungus Teluk Kabung (Pesisir Selatan). Gambir diperoleh dari Kenagarian Siguntur Muda, kecamatan Koto XI Tarusan, kabupaten Pesisir Selatan. Bahan proses yang digunakan adalah etil asetat teknis, etanol $70 \%$ dan aqudest. Bahan kimia untuk analisis produk, yaitu aguades, metanol, standar katekin, plate count agar (PCA) dan peptone water (PW).

Peralatan yang digunakan untuk proses ekstraksi katekin dari gambir adalah timbangan, saringan, alat press, water bath dan ayakan 100 mesh dan 200 mesh (Humboldt). Alat untuk pengolahan ikan teri adalah wadah pencucian, para-para bambu, dan kemasan. Peralatan analisis sampel adalah timbangan digital (Kern-ABJ 220-4M), oven (Memmert), desikator (Duran, Mobilex), penjepit, gunting, cawan porselen, autoclav (GEA, LS-50LJ), peralatan gelas, petri dish, pipet ukur, tabung reaksi, rak tabung reaksi, rak tabung reaksi, jarum ose, erlemeyer, batang pengaduk, lampu spritus, vortex (Merk), lemari pengeram (Memmert), colony counter (Galaxy 230), bunsen, cawan petri dan peralatan pengujian.

\subsection{Pembuatan ekstrak katekin}

Pembuatan ekstrak katekin dari gambir menggunakan metoda (Yeni et al., 2017), yaitu ekstrak ulang gambir asalan. Proses dilakukan dengan mengekstrak ulang gambir asalan yang bertujuan untuk menghilangkan pengotor dan dilanjutkan dengan pelarut organik untuk mendapatkan katekin dengan kadar tertentu.

\subsubsection{Ekstraksi ulang dengan air}

Gambir asalan dihaluskan, dilarutkan dengan aquades suhu $\pm 70^{\circ} \mathrm{C}(1: 5)$ dan disaring menggunakan saringan dengan ukuran bertingkat, yaitu 100 dan 200 mesh. Filtrat hasil penyaringan diendapkan selama 20-24 jam. Endapan yang diperoleh dilanjutkan dengan pencucian 
ulang menggunakan air dingin sampai diperoleh larutan kekuningan. Endapan yang diperoleh dipress untuk memisahkan air yang tersisa dan dikeringkan pada suhu ruang 35-40 jam (gambir murni).

\subsubsection{Ekstraksi dengan pelarut organik}

Gambir murni kering dilarutkan menggunakan etil asetat dan etanol dengan dengan perbandingan $1: 10$. Larutan gambir dimaserasi \pm 4 jam dan disaring menggunakan saringan 100 mesh. Filtrat yang diperoleh dikeringkan 5-6 jam dengan water bath dan diayak menggunakan ayakan 100 mess. Hasil ekstrak katekin dilakukan analisa terhadap kadar air, abu (gravimetri), tanin dan katekin (spektrofotometri), masing-masing sampel dilakukan dua kali ulangan.

\subsection{Pengawetan ikan teri}

Ikan teri segar yang diambil dari nelayan di Bungus dibersihkan dan dicuci dengan air mengalir untuk menghilangkan pengotor seperti pasir. Ikan teri yang telah dicuci ditiriskan dalam keranjang, selanjutnya dicelupkan ke dalam air panas \pm 1 menit, ditiriskan kembali dan ditimbang sesuai perlakuan.

Katekin dari gambir dilarutkan dengan air untuk membuat konsentrasi $0 \%, 5 \%, 10 \%, 15 \%(\mathrm{w} / \mathrm{v})$. Ikan teri disiapkan sebanyak $\pm 250 \mathrm{~g}$ lalu direndam dalam larutan katekin \pm 2 jam sesuai variasi konsentrasi yang telah ditetapkan dengan perbandingan larutan ekstrak katekin dengan ikan teri $4: 1$. Ikan teri hasil perlakuan dikeringkan dalam oven pada suhu $\pm 50^{\circ} \mathrm{C}$ selama $12-24$ jam dengan kadar air diperkirakan 16\% sesuai kadar air rata-rata pengeringan tradisional (Savitri et al., 2018).

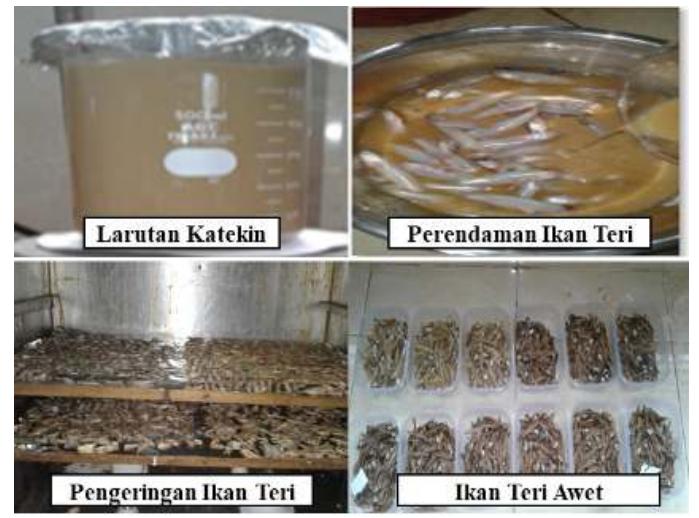

Gambar 1. Proses dan produk pengawetan ikan teri awet dengan katekin.

Pembuatan ikan teri awet dengan katekin sesuai perlakuan, kemudian dikemas menggunakan plastik polipropilen (PP) dan disimpan pada suhu kamar. Ikan teri awet dengan katekin dilakukan analisa mutu terhadap ketahanan simpan pada 0, 15 dan 30 hari, masing-masing perlakuan dilakukan dua kali ulangan.

\subsection{Karakterisasi}

Ikan hasil pengawetan pada penelitian ini dilakukan karakterisasi sebelum dan sesudah pengawetan terhadap kadar air, kadar abu dan total mikroba sesuai perlakuan. Uji organoleptik (warna, aroma, tekstur) dilakukan oleh 15 orang panelis menggunakan kesukaan (hedonik), yaitu sangat suka (5), suka (4), biasa (3), kurang suka (2) dan tidak suka (1).

\section{Hasil dan pembahasan \\ 3.1. Karateristik mutu ekstrak gambir}

Hasil uji ekstrak ulang gambir asalan menunjukkan katekin yang digunakan tergolong gambir murni (Yeni et al., 2017) dan gambir mutu I berdasarkan SNI. 013391:2000. Hasil analisis ekstrak katekin seperti terlihat pada Tabel 1.

Kandungan katekin dalam gambir merupakan karakteristik yang menentukan tingkat mutu. Hal ini disebabkan katekin merupakan substituen utama gambir dengan kebutuhan yang cukup banyak dalam industri dibandingkan unsur lain seperti tanin. Katekin dalam keadaan murni memberikan rasa manis, berbentuk kristal, berwarna putih sampai kekuningan. Untuk menghasilkan kandungan katekin yang tinggi dilakukan melalui proses ekstraksi ulang gambir. Teknologi proses dilakukan berdasarkan perbedaan sifat kelarutan antara katekin dan tanin dalam air. Katekin dalam keadaan murni sulit larut dalam air dingin, mudah larut dalam air panas, larut dalam alkohol dan etil asetat (Anova and Yeni, 2020; Yeni et al., 2019, 2014).

Tabel 1

Karakterisasi ekstrak katekin yang digunakan sebagai pengawet ikan teri.

\begin{tabular}{lll}
\hline Parameter & $\begin{array}{l}\text { Persyaratan SNI. 01- } \\
3391: 2000\end{array}$ & $\begin{array}{l}\text { Kandungan } \\
\text { bahan }\end{array}$ \\
\hline Kadar air & Maks. 14\% & $10,14 \%$ \\
Kadar abu & Maks. 5\% & $1,64 \%$ \\
Kadar katekin & Min. 60\% & $82,64 \%$ \\
Kadar tanin & - & $5,58 \%$ \\
\hline
\end{tabular}

\subsection{Karakteristik mutu ikan teri 3.2.1. Kadar air dan abu}

Hasil analisis kadar air ikan teri awet dengan katekin (Tabel 2) menunjukkan semakin tinggi konsentrasi katekin yang digunakan pada proses perendaman, makin tinggi kandungan air pada ikan teri awet dengan katekin. Kadar air tertinggi diperoleh pada perlakuan konsentrasi katekin 15\% (A4), yaitu 19,3494\% dan terendah konsentrasi katekin $0 \%$ (tanpa perendaman katekin) (A1), yaitu 16,2068\%. Hasil pengujian kadar air ikan teri awet dengan katekin cukup rendah, dimana syarat mutu ikan teri nasi (Stolephorus sp) kering berdasarkan SNI.01-3461:2013 adalah maks. 60\%.

Peningkatan kadar air yang semakin tinggi dengan makin tinggi konsentrasi katekin dapat disebabkan pada proses perendaman, senyawa katekin diserap ke dalam tubuh ikan teri dan proses pengeringan menurunkan aktivitas air pada ikan. Senyawa katekin yang terapsorbsi pada ikan teri mengakibatkan terhambatnya uap air yang keluar pada saat proses pengeringan. Menurut (Sari et al., 2017), penurunan aktivitas air pada ikan disebabkan oleh katekin dari gambir dapat mengurangi kemampuan menahan air (water holding capacity) oleh perubahan- 
perubahan akibat pemanasan yang tidak dapat kembali lagi yang menyebabkan kadar air menjadi tinggi.

Kadar air yang tinggi merupakan salah satu penyebab kerusakan bahan pangan sehingga dalam pengolahan pangan air sering dikeluarkan atau dikurangi dengan cara penguapan atau pengeringan. Kadar air yang rendah dapat memperpanjang umur simpan pangan karena dapat menstabilkan aktivitas dan menahan laju peningkatan jumlah miroba. Umur simpan pada suatu produk akan mempengaruhi kualitas kandungan bahan yang ada didalamnya (Juwitaningtyas and Nurul Khairi, 2018; Sundari et al., 2015).

Kadar air dalam bahan makanan sangat mempengaruhi kualitas dan daya simpan dari suatu produk terhadap mikroorganisme yang dinyatakan dengan Aw, yaitu jumlah air bebas yang dapat digunakan untuk pertumbuhannya. Analisis kadar air dilakukan untuk penentuan umur simpan produk dengan metode konvensional (Herawati, 2008; Sundari et al., 2015).

Tabel 2

Pengaruh konsentrasi katekin dari gambir terhadap kadar air dan abu ikan teri.

\begin{tabular}{lll}
\hline Perlakuan & Kadar air & Kadar abu \\
\hline A1 $(0 \%)$ & $16,2068 \mathrm{a}$ & $12,2507 \mathrm{a}$ \\
A2 $(5 \%)$ & $17,2121 \mathrm{~b}$ & $11,3350 \mathrm{a}$ \\
A3 $(10 \%)$ & $18,1339 \mathrm{c}$ & $10,5358 \mathrm{~b}$ \\
A4 $(15 \%)$ & $19,3494 \mathrm{~d}$ & $9,5306 \mathrm{~b}$
\end{tabular}

Keterangan : Angka-angka yang diikuti oleh huruf yang sama pada kolom yang sama berarti berbeda tidak nyata.

Kualitas suatu bahan pangan juga dipengaruhi oleh kadar abu. Penetapan kadar abu bertujuan untuk memberikan gambaran tentang kandungan mineral internal dan eksternal yang berasal dari proses awal sampai terbentuknya ekstrak. Kandungan abu bahan pangan dan komposisinya tergantung pada jenis bahan dan cara pengabuannya yang dapat menunjukan total mineral dalam suatu bahan pangan. Bahan pangan terdiri dari $96 \%$ bahan organik dan air, sedangkan sisanya merupakan unsur-unsur mineral yang dikenal sebagai zat organik. Bahan-bahan organik dalam proses pembakaran akan terbakar tetapi komponen anorganiknya tidak dan disebut sebagai kadar abu (Aditya and Ariyanti, 2016; Kamsina et al., 2020; Setyaningsih et al., 2014; Sundari et al., 2015).

Hasil analisis kadar abu ikan teri awet kering menunjukkan kadar abu tertinggi diperoleh pada konsentrasi $0 \%$ (tanpa perendaman katekin), yaitu $12,2507 \%$ dan terendah pada konsentrasi katekin 15\% $(9,5306 \%$ ) (Tabel 2). Kadar abu yang tinggi pada konsentrasi $0 \%$ dapat disebabkan oleh proses pencucian kurang bersih terhadap ikan teri, dimana masih terdapat pengotor seperti pasir, kemudian ikan teri langsung dikeringkan. Ikan teri melalui proses perendaman dengan katekin dilakukan penyaringan kembali sehingga senyawa pengotor seperti pasir sebagai senyawa anorganik dapat terbuang dalam saringan. Menurut (Kasim et al., 2015), kadar abu pada suatu bahan bersumber dari bahan itu sendiri atau telah ada di dalam tanaman dan mineral yang terbawa pada saat proses pengolahan.

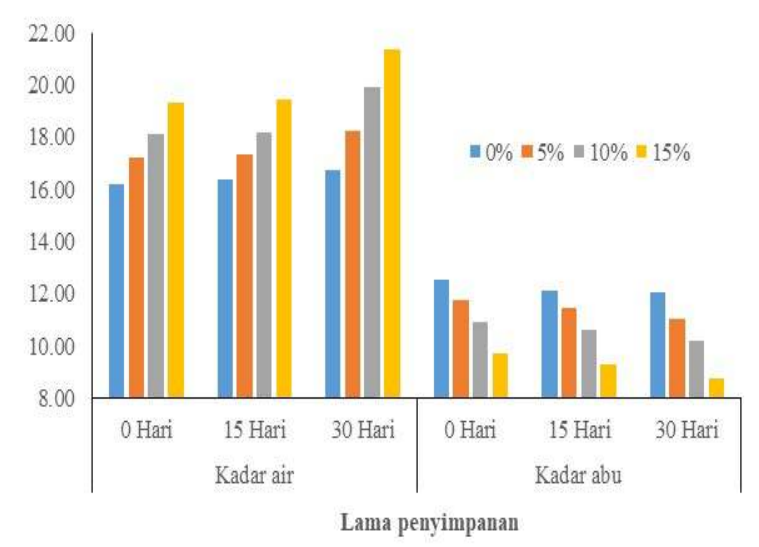

Gambar 2. Pengamatan lama penyimpanan terhadap kadar air dan abu ikan teri awet dengan katekin gambir.

Uji ketahanan simpan ikan teri awet dengan menunjukkan semakin lama penyimpanan terjadi peningkatan kadar air dan penurunan kadar abu (Gambar 2). Kadar air suatu bahan yang dikeringkan dipengaruhi oleh tingkat penguapan yang didapat selama proses pengeringan. Ikan teri yang direndam dengan larutan katekin akan terlapisi. Semakin tinggi konsentrasi yang digunakan menyebabkan ikan tertutup senyawa katekin makin tebal dan menyulitkan pengeluaran air. Peningkatan kadar air juga dapat disebabkan sifat higroskopis dari katekin. Semakin tinggi kadar katekin, kadar air makin tinggi yang menunjukkan sifat higroskopis produk makin tinggi (Sari et al., 2017).

Selain pengaruh bahan yang digunakan, peningkatan kadar air pada suatu bahan selama penyimpanan dapat dipengaruhi oleh kelembaban nisbi udara disekitarnya. Kadar air yang rendah pada bahan sedangkan kelembaban udara sekitarnya tinggi, maka akan terjadi penyerapan uap air dari udara sehingga bahan menjadi basah atau kadar airnya menjadi lebih tinggi (Anova and Kamsina, 2018; Herawati, 2008; Sari et al., 2017).

\subsubsection{Total bakteri}

Katekin dari gambir merupakan senyawa polifenol yang kompleks, potensial sebagai antimikroba dan antioksidan. Senyawa antioksidan dapat menghambat terjadinya reaksi oksidasi dan mencegah terjadinya ketengikan pada bahan pangan. Penghambatan katekin terhadap bakteri oleh polifenol atau katekin dari gambir tertuju pada dinding sel bakteri. Katekin berikatan dengan unit peptida pada komponen peptidoglikan dari dinding sel. Akibat dari pengikatan ini dapat mengacaukan integritas dinding sel bakteri dan menyebabkan kebocoran pada sel bakteri gram-positif, seperti Staphylococcus mutants, S. aureus dan B. subtilis (Kresnawaty and Zainuddin, 2009; Mat Saad et al., 2020; Pambayun et al., 2007).

Menurut (Magdalena and Kusnadi, 2015), senyawa flavonoid yang bersifat polar lebih mudah menembus lapisan peptidoglikan yang juga bersifat polar pada bakteri Gram positif daripada lapisan lipid non polar 
(komplek) pada bakteri Gram negatif. Bakteri Gram positif lebih mudah rusak oleh katekin gambir, hal disebabkan struktur dinding sel bakteri Gram positif lebih sederhana, yaitu berlapis tunggal dengan kandungan lipid yang rendah sehingga memudahkan bahan bioaktif masuk ke dalam sel. Katekin dari gambir akan menganggu fungsi dinding sel, menyebabkan lisis pada sel.

Penggunaan senyawa flavonoid dalam konsentrasi rendah, akan membentuk kompleks lemah pada protein bakteri kemudian dapat menyebabkan presipitasi dan denaturasi protein bakteri. Konsentrasi yang tinggi, flavonoid akan menyebabkan koagulasi protein bakteri dan menyebabkan membran sitoplasma pada bakteri terjadi lisis. Sehingga faktor konsentrasi zat antimikrobial dan cara proses merupakan faktor penting yang harus diperhitungkan. Proses pemanfaatan katekin sebagai pengawet ikan teri dilakukan dengan cara pengolahan basah dan kering. Pengolahan cara basah memberikan penghambatan lebih tinggi terhadap mikroorganisme dibanding cara kering (Yunus et al., 2009).

Berdasarkan hasil uji jumlah mikroba ikan teri dengan katekin menggunakan pengolahan cara basah menunjukkan terjadi penurunan dengan meningkatnya konsentrasi katekin, yaitu perlakuan tanpa katekin, yaitu $1,36 \times 10^{5} \mathrm{koloni} / \mathrm{g}$ dan terendah perlakuan A4B3, yaitu $1,10 \times 10^{5} \mathrm{koloni} / \mathrm{g}$ (Tabel 3).

Tabel 3. Pengaruh konsentrasi katekin gambir dan lama penyimpanan terhadap total bakteri koloni ikan teri awet dengan katekin

\begin{tabular}{ll}
\hline Perlakuan & Total bakteri koloni/g \\
\hline A1 $(0 \%)$ & $1,36 \times 10^{5} \mathrm{a}$ \\
A2 $(5 \%)$ & $1,23 \times 10^{5} \mathrm{~b}$ \\
A3 $(10 \%)$ & $1,10 \times 10^{5} \mathrm{c}$ \\
A4 $(15 \%)$ & $1,12 \times 10^{5} \mathrm{~d}$ \\
\hline
\end{tabular}

Keterangan : angka-angka yang diikuti oleh huruf yang sama pada kolom yang sama berarti berbeda tidak nyata.

Hasil penelitian menujukkan penggunaan konsentrasi katekin $10 \% \quad$ (A4B3) sudah dapat mengurangi pertumbuhan bakteri untuk mengawetkan ikan teri. Jumlah bakteri yang terkandung pada ikan teri hasil perlakuan masih tergolong aman dikonsumsi, dimana jumlah bakteri (ALT) maksimum untuk ikan yang diawetkan adalah $1 \times 10^{5}$ koloni/gram (SNI.013461:2013). Perlakuan penelitian menunjukkan penggunaan katekin, tidak dapat mematikan semua bakteri yang ada pada ikan teri walaupun ikan teri dikeringkan.

Hasil pengamatan terhadap ketahanan simpan ikan teri awet kering selama 30 hari memperlihatkan terjadi penurunan total bakteri, jumlah bakteri terendah terdapat pada konsentrasi katekin 10\% (A3B3), yaitu $0,69 \times 10^{5}$ koloni/g (Gambar 3). Penurunan total bakteri dapat disebabkan oleh senyawa tanin dan senyawa lain seperti flavonoid serta alkaloid yang juga sebagai anti mikroba terdapat dalam ekstrak. Senyawa aktif ini dapat menginaktifkan dan menghambat pertumbuhan bakteri. Hal ini menunjukkan semakin meningkat konsentrasi, larutan katekin akan makin banyak berpenetrasi ke dalam daging ikan teri sampai batas tertentu dan makin besar kemampuannya menginaktifkan dan menghambat pertumbuhan bakteri.

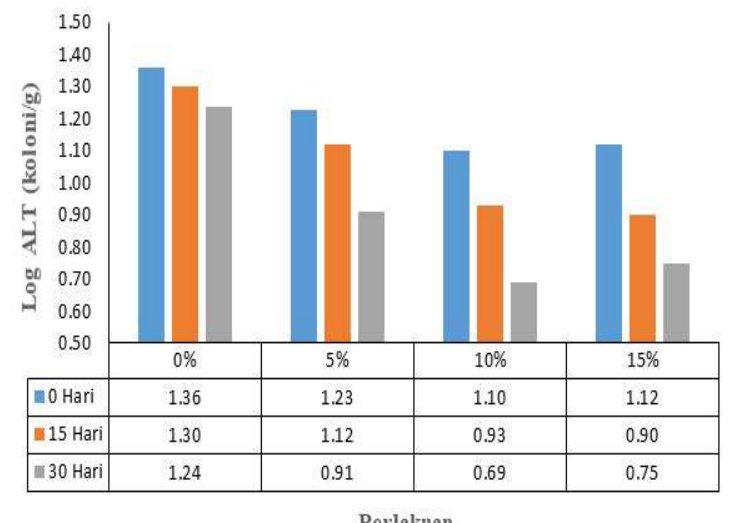

Gambar 3. Pengamatan lama penyimpanan terhadap Log total bakteri (TPC) ikan teri awet dengan katekin gambir.

Senyawa tanin dari gambir adalah polimer fenolik mempunyai sifat antimikroba dan bersifat racun terhadap khamir, bakteri, dan kapang. Kemampuan tanin sebagai antimikroba karena tanin akan berikatan dengan dinding sel bakteri sehingga akan menginaktifkan kemampuan menempel bakteri, menghambat pertumbuhan, mengurangi aktivitas enzim protease dan membentuk ikatan komplek dengan polisakarida (Yanti et al., 2008).

Flavonoid dapat berperan secara langsung sebagai antimikroba dengan menggangu fungsi dari metabolisme mikroorganisme seperti bakteri. Mekanisme antimikroba flavonoid, yaitu dengan cara mengganggu aktivitas transpeptidase peptidoglikan sehingga pembentukan dinding sel bakteri terganggu dan sel mengalami lisis. Alkaloid mempunyai pengaruh sebagai bahan antimikroba dengan mekanisme penghambatannya dengan cara mengkelat DNA (Afrianti et al., 2013).

Menurut (Sari et al., 2017), bahan antimikrobial apabila diberikan pada bakteri, bahan tersebut tidak akan membunuh semua sel bakteri pada saat yang sama, melainkan sel-sel itu akan terbunuh dalam suatu periode waktu dengan laju eksponensial yang konstan. Jumlah bakteri yang tersisa dapat bertahan hidup dan akan terus berkembang biak jika kondisi substrat mendukung kehidupannya. Kondisi ini harus dipertimbangkan bagi efektifnya dalam penerapan metode pengendalian bakteri pada produk pengolahan hasil perikanan seperti halnya pemakaian larutan katekin pada proses pengawetan ikan teri.

Perkembangbiakan mikroorganisme seperti bakteri, kapang juga dipengaruhi oleh faktor kelembaban, temperatur, dan ketersediaan oksigen. Ketersediaan oksigen dipengaruhi oleh pengemas plastik pada saat penyimpanan di suhu ruang. Penyimpanan ikan teri dalam penelitian ini menggunakan kemasan plastik polypropylene (PP). Plastik PP permeabilitasnya terhadap oksigen lebih rendah dengan permukaannya yang licin, lebih tahan suhu tinggi dan lebih efektif menurunkan total bakteri pada daging dibandingkan dengan plastik PE (Yanti et al., 2008). 


\subsubsection{Organoleptik A. Tekstur}

Hasil uji organoleptik terhadap tekstur ikan teri awet dengan katekin pengaruh perlakuan konsentrasi katekin dan lama penyimpanan menunjukkan konsentrasi $10 \%$ (A3) memiliki persentase tertinggi $(60,00 \%)$ sangat suka sampai suka dan terendah tanpa penggunaan katekin (Gambar 4). Semakin tinggi konsentrasi gambir makin tinggi nilai tekstur. Nilai tekstur yang diterima panelis, yaitu ikan teri awet dengan katekin memiliki spesifikasi padat, kering dan tidak mudah patah.

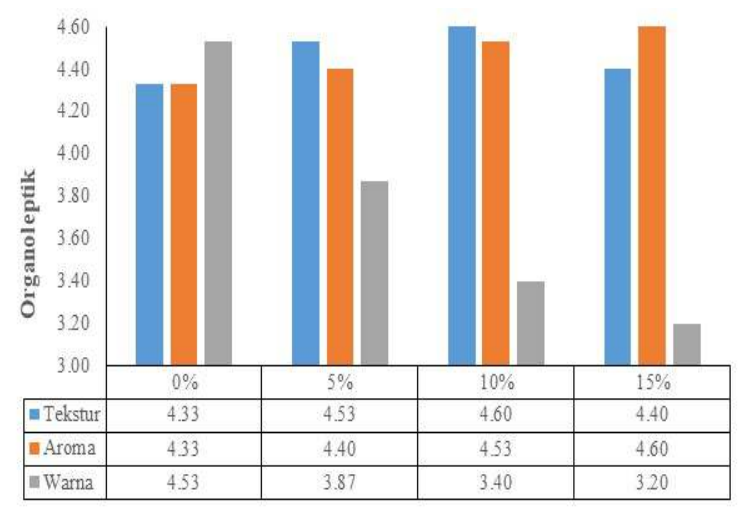

Konsentrasi katekin

Gambar 4. Hasil analisa uji organoleptik ikan teri awet dengan katekin pada konsentrasi berbeda.

Keterangan:

Nilai tekstur $=5=$ Sangat suka, $4=$ suka, $3=$ Agak suka, $2=$ kurang suka, $1=$ tidak suka.

Uji ketahanan simpan ikan teri awet katekin selama 30 hari menunjukkan terjadi penurunan nilai tekstur tingkat kesukaan panelis, terutama yang menggunakan katekin sebagai pengawet (Gambar 5). Penilaian tekstur pada konsentrasi 10\% (A3) dan 15\% (A4) tidak berbeda nyata dan masih berada rentang nilai suka sampai agak suka. Nilai tekstur ikan teri tanpa pengawet memiliki nilai tekstur masih disukai panelis dibandingkan menggunakan katekin.

Hasil perlakuan penelitian memperlihatkan semakin tinggi konsentrasi katekin, tekstur ikan teri makin kurang kompak. Penurunan nilai tekstur dapat disebabkan proses higroskopis dalam penyimpanan, kadar air meningkat dan ikan teri menjadi kurang padat atau lembek. Hal ini dapat juga disebabkan pada proses pengeringan terjadi oksidasi, katekin berubah menjadi tanin terpolimerisasi yang memiliki sifat menguraikan dan menggumpalkan protein. Akibat terbentuknya penggumpalan protein oleh tanin mengakibatkan lapisan permukaan menjadi mengeras dan kering, sehingga uap air di lapisan dalam ikan menjadi terhambat sampai kepermukaan (Sari et al., 2017; Yeni et al., 2017).

Menurut (Sari et al., 2020), perbedaan kekuatan tekstur ikan dapat disebabkan pada saat penambahan katekin terjadi introduksi katekin bertemu protein yang menyebabkan lendir pada ikan hilang. Reaksi tersebut membentuk perubahan kimia tertentu seperti terjadinya pengumpalan protein pada permukaan bahan tertentu.
Saat pengeringan terbentuk dekstrin dari pati (karbohidrat), bahan masih masif dan keras pada permukaan bahan tetapi bagian dalam masih lembut.

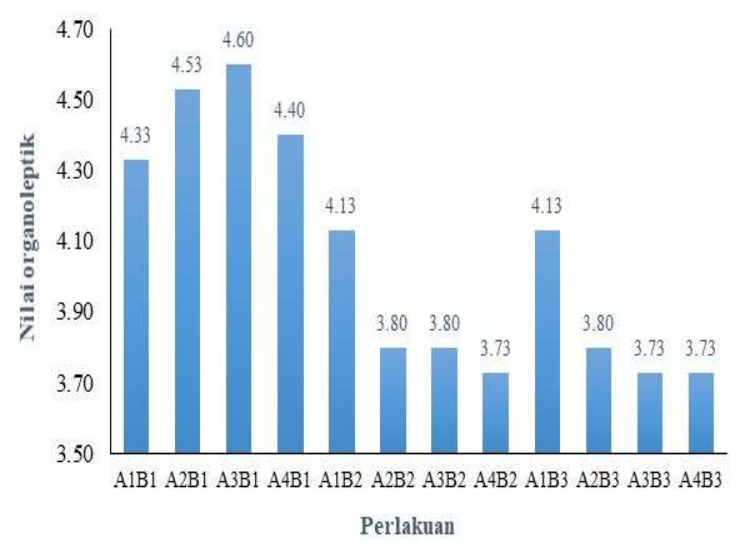

Gambar 5. Persentase rata-rata nilai tekstur ikan teri awet katekin dalam penyimpanan

Keterangan:

Nilai tekstur $=5=$ Sangat suka, $4=$ suka, $3=$ Agak suka, $2=$ kurang suka, $1=$ tidak suka.

Perlakuan $=\mathrm{A} 1$ : katekin $0 \%$, A2: katekin 5\%, A3: katekin $10 \%$, A4: katekin 15\%. B1: lama penyimpanan 0 hari, B2: lama penyimpanan 15 hari dan B3: lama penyimpanan 30 hari.

\section{B. Aroma}

Hasil uji organoleptik ikan teri awet katekin terhadap aroma menunjukkan peningkatan konsentrasi katekin menghasilkan nilai yang makin disukai panelis (Gambar 4). Nilai aroma suka dengan persentase tertinggi diperoleh pada perlakuan (A4B1), yaitu 73,33\% dan terendah pada perlakuan A1B1 (20,00\%). Penggunaan katekin sebagai pengawet ikan teri dapat menghilangkan bau amis, dimana semakin tinggi konsentrasi tingkat keamisan ikan teri makin kecil dan panelis lebih menyukai ikan teri dengan aroma yang tidak amis.

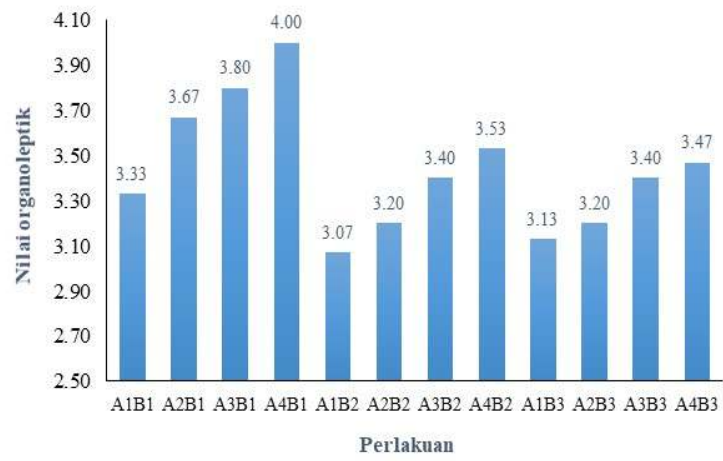

Gambar 6. Persentase rata-rata nilai aroma ikan teri awet katekin dalam penyimpanan.

Keterangan:

Nilai tekstur $=5=$ Sangat suka, $4=$ suka, $3=$ Agak suka, $2=$ kurang suka, $1=$ tidak suka.

Perlakuan $=$ A1: katekin 0\%, A2: katekin 5\%, A3: katekin $10 \%$, A4: katekin $15 \%$. B1: lama penyimpanan 0 hari, B2: lama penyimpanan 15 hari dan B3: lama penyimpanan 30 hari. 
Perlakuan penyimpanan terhadap ikan teri awet katekin selama 30 hari menunjukkan terjadi penurunan terhadap tingkat kesukaan panelis dengan nilai agak sampai cukup suka untuk semua perlakuan (Gambar 6). Penilaian terhadap aroma ikan teri awet katekin pada konsentrasi $10 \%$ (A3) dan 15\% (A4) tidak berbeda nyata dan berada pada rentang suka sampai agak suka.

\section{Warna}

Hasil uji organoleptik ikan teri awet katekin terhadap warna menunjukkan peningkatan konsentrasi katekin menghasilkan warna yang makin gelap dan kurang disukai panelis. Panelis lebih menyukai ikan teri dengan warna putih yang diperoleh pada perlakuan tanpa penggunaan katekin $0 \%$ (A1) dengan persentase tertinggi sangat suka, yaitu 53,33\% dan terendah pada konsentrasi $15 \%(13,33 \%)$. Ikan teri yang direndam menggunakan katekin menghasilkan warna coklat setelah proses pengeringan dengan makin tinggi konsentrasi. Hal ini dapat disebabkan sifat katekin dalam keadaan terbuka mudah teroksidasi yang menyebabkan warna produk menjadi lebih gelap (Yeni et al., 2019, 2017).

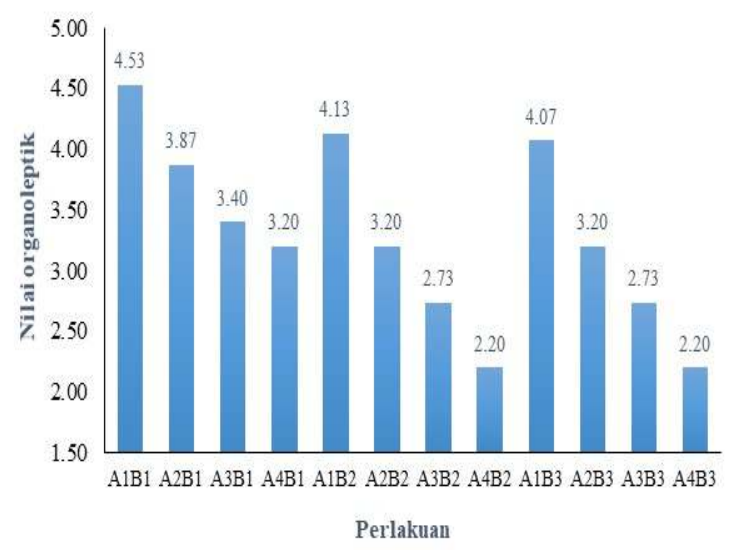

Gambar 7. Persentase rata-rata nilai warna ikan teri awet katekin dalam penyimpanan

Keterangan:

Nilai tekstur $=5=$ Sangat suka, $4=$ suka, $3=$ Agak suka, $2=$ kurang suka, $1=$ tidak suka.

Perlakuan $=\mathrm{A} 1$ : katekin $0 \%$, A2: katekin 5\%, A3: katekin $10 \%$, A4: katekin 15\%. B1: lama penyimpanan 0 hari, B2: lama penyimpanan 15 hari dan B3: lama penyimpanan 30 hari.

Uji organoleptik ikan teri awet dengan katekin terhadap warna, pengaruh lama penyimpanan sampai 30 hari terjadi penurunan nilai, yaitu agak suka sampai tidak suka. Nilai warna tertinggi (suka) masih diperoleh pada perlakuan tanpa penggunaan katekin (konsentrasi 0\%). Penggunaan katekin pada konsentrasi katekin lebih rendah, yaitu 5\% (A2) memiliki presentasi agak suka tertinggi (80\%), diikuti konsentrasi katekin 10\% (A3) dan $15 \%$ (A4), yaitu kurang suka. Hasil penelitian menunjukkan penggunaan katekin sebagai pengawet menghasilkan warna ikan teri yang kurang disukai panelis. Untuk itu, perlu didapatkan proses pengawetan ikan teri dengan katekin dan teknik pengeringan yang sesuai untuk memperoleh ikan teri awet yang disukai konsumen.

\section{Kesimpulan}

Perlakuan konsentrasi larutan katekin dari gambir sebagai pengawet ikan teri melalui perendaman menghasilkan ikan teri yang lebih awet dibandingkan tanpa perendaman dengan larutan katekin terutama mengurangi jumlah bakteri (TPC). Penggunaan konsentrasi katekin $10 \% \quad$ (A4B3) sudah dapat mengurangi pertumbuhan bakteri pada ikan teri dengan jumlah bakteri terkecil dari semua perlakuan, yaitu $1,10 \times 10^{5} \mathrm{koloni} / \mathrm{g}$, kadar air $(18,1339 \%$,) dan abu $(10,5358 \%)$.

Uji ketahanan simpan ikan teri menggunakan pengawet katekin sampai 30 hari masih memenuhi persyaratan mutu ikan teri kering berdasarkan SNI.013461:2013. Hasil uji organoleptik pada konsentrasi 10\% terhadap tekstur dan aroma memiliki presentase sangat suka, masing-masing $60,00 \%$ dan $13,33 \%$. Penilaian terhadap warna, makin tinggi konsentrasi katekin warna kurang disukai panelis. Panelis lebih menyukai ikan teri dengan warna putih yang diperoleh pada perlakuan konsentrasi katekin 0\% (A1B1) dengan persentase tertinggi sangat suka, yaitu 53,33\%.

\section{Ucapan terima kasih}

Penulis berterima kasih pada pimpinan Balai Riset dan Standardisasi Industri Padang dan Universitas Eka Sakti yang telah memfasilitasi terlaksananya penelitian ini.

\section{Daftar pustaka}

Aditya, M., Ariyanti, P.R., 2016. Manfaat gambir (Uncaria gambir Roxb) sebagai antioksidan. Majority 5, 129-133.

Afrianti, M., Dwiloka, B., Setiani, B., 2013. Total bakteri, $\mathrm{pH}$, dan kadar air daging ayam broiler setelah direndam dengan ekstrak daun senduduk (Melastoma Malabathricum L.) selama masa simpan. J. Pangan dan Gizi 4, 49-55. https://doi.org/10.26714/ jpg.4.1.2013.

Anova, I.T., Kamsina, K., 2018. Pengaruh penggunaan ekstrak gambir sebagai antimikroba terhadap mutu dan ketahanan simpan cake bengkuang (Pachyrrhizus erosus) T. J. Litbang Ind. 8, 111-117. https://doi.org/10.24960/jli.v8i2.4329.111-117

Anova, I.T., Yeni, G., 2020. Rasio pelarut etanol dan etil asetat pada proses ekstraksi terhadap karakteristik katekin dari gambir. J. Litbang Ind. 10, 121-127. https://doi.org/http://dx.doi.org/10.24960/jli.v10i2.65 06.121-127

Asiah, N., Cempaka, L., David, W., 2018. Pendugaan umur simpan produk pangan, Ub Press.

Herawati, H., 2008. Penentuan umur simpan pada produk pangan. J. Litbang Pertan. 27, 124-130.

Juwitaningtyas, T., Nurul Khairi, A., 2018. Identifikasi pengaruh umur simpan dan antioksidan terhadap kandungan karbohidrat dan kadar air pada mie tapioka basah. Chem. J. Tek. Kim. 5, 21. https://doi.org/10.26555/chemica.v5i1.11837

Kamsina, K., Firdausni, F., Silfia, S., 2020. Pemanfaatan katekin ekstrak gambir (Uncaria gambir Roxb) 
sebagai pengawet alami terhadap karakteristik mie basah. J. Litbang Ind. 10, 89-95. https://doi.org/10.24960/jli.v10i2.6526.89-95

Kasim, A., Asben, A., Mutiar, S., 2015. Kajian kualitas gambir dan hubungannya dengan karakteristik kulit tersamak. Maj. Kulit, Karet, dan Plast. 31, 55-64.

Kresnawaty, I., Zainuddin, A., 2009. Aktivitas antioksidan dan antibakteri dari derivat metil ekstrak etanol daun gambir (Uncaria gambir). J. Penelit. Tanam. Ind. 15, 145-151. https://doi.org/10.21082/ jlittri.v15n4.2009.145-151

Magdalena, N.V., Kusnadi, J., 2015. Antibacterial from gambier leaves crude extract (Uncaria gambir var Cubadak) microwave-assisted extraction method against bacterial Pathogens. J. Pangan dan Agroindustri 3, 124-135.

Mat Saad, M.F., Goh, H.H., Rajikan, R., Tuan Yusof, T.R., Baharum, S.N., Bunawan, H., 2020. From phytochemical composition to pharmacological importance. Trop. J. Pharm. Res. 19, 1767-1773. https://doi.org/10.4314/tjpr.v19i8.28

Melia, S., Novia, D., Juliyarsi, I., 2015. Antioxidant and antimicrobial activities of gambir (Uncaria gambir Roxb) extracts and their application in rendang. Pakistan J. Nutr. 14, 938-941. https://doi.org/ 10.3923/pjn.2015.938.941

Pambayun, R., Gardjito, M., Sudarmadji, S., Kuswanto, K.R., 2007. Kandungan fenol dan sifat antibakteri dari berbagai jenis ekstrak produk gambir (Uncaria gambir Roxb). Maj. Farm. Indones. 18, 141-146.

Rosaini, H., Rasyid, R., Hagramida, V., 2015. Penetapan kadar protein secara kjedahl beberapa makanan olahan kerang remis (Corbiculla moltkiana Prime.) dari Danau Singkarak. J. Farm. Higea 7, 120-127.

Sari, S.R., Agustini, S., Wijaya, A., Pambayun, R., 2017. Profil mutu ikan lele (Clarias Gariepinus) asap yang diberi perlakuan gambir (Uncaria gambir Roxb.). J. Din. Penelit. Ind. 28, 101-111.

Sari, S.R., Guttifera, Pambayun, R., Wijaya, A., Prariska, D., Puteri, R.E., 2020. Perbaikan tekstur ikan lele (Clarias gariepinus) asap dengan gambir (Uncaria gambir Roxb) sebagai potensi usaha di desa Sungai Dua. J. Ilmu Perikan. Air Tawar 1.

Savitri, I.K.E., Silaban, B., Sormin, R.B.D., 2018. Mutu produk teri (Stolephorus sp.) kering Pulau Bru dengan metode pengering surya tertutup. JPHPI 21, 543-548.

Setyaningsih, D., Pandji, C., Perwatasari, D.D., 2014. Kajian aktivitas antioksidan dan antimikroba fraksi dan ekstrak dari daun dan ranting jarak pagar (Jatropha curcas L.) serta pemanfaatannya pada produk Personal Hygiene. Agritech 34, 126-137. https://doi.org/10.22146/agritech.9502

Silvia, R., Waryani, S.W., Hanum, F., 2015. Pemanfaatan kitosan dari cangkang bekicot (Achatina fulica) sebagai pengawet ikan kembung (Rastrelliger sp) dan ikan lele (Clarias batrachus). J. Tek. Kim. USU 3, 51-57. https://doi.org/10.32734/jtk.v3i4.1656

Sundari, D., Almasyhuri, Lamid, A., 2015. Pengaruh proses pemasakan terhadap komposisi zat gizi bahan pangan sumber protein. Media litbangkes 25, 235242.

Suraini, S., Chairani, C., Enlita, E., 2015. Uji aktivitas antijamur ekstrak gambir (Uncaria gambir Roxb) terhadap Candida albicans secara in vitro. Scientia 5 , 62-64. https://doi.org/10.36434/scientia.v5i2.23

Yanti, H., Elfawati, Hidayati, 2008. Kualitas daging sapi dengan kemasan plastik PE (Polyethylen) dan plastik PP (Polypropylen). J. Peternak. 5, 22-27.

Yeni, G., Silfia, S., Diza, Y.H., 2019. Pengaruh jenis pelarut dan kecepatan homogenizer terhadap karakteristik partikel katekin gambir. J. Litbang Ind. 9, 9-14. https://doi.org/http://dx.doi.org/10.24960/ jli.v9i1.5227.9-14

Yeni, G., Syamsu, K., Mardliyati, E., Muchtar, H., 2017. Penentuan teknologi proses pembuatan gambir murni dan katekin terstandar dari gambir asalan. J. Litbang Ind. 7, 1. https://doi.org/10.24960/jli.v7i1.2846.1-10

Yeni, G., Syamsu, K., Suparno, O., Mardliyati, E., Muchtar, H., 2014. Repeated extraction process of raw gambiers (Uncaria gambier Robx.) for the catechin production as an antioxidant. Int. J. Appl. Eng. Res. 9.

Yunus, Arisandi, A., Abida, I.W., 2009. Daya hambat ekstrak metanol rumput laut (Euchema spinosum) terhadap bakteri Aeromonas hydrophila. J. Kelaut. 2, 99-105. 